\title{
Immunohistochemical expression of pericytes and myofibroblasts in the extracellular matrix of oral actinic cheilitis and squamous cell carcinoma: a comparative study
}

Flávia Godinho Wanderley ${ }^{a}$, Carlla Silva Nunes ${ }^{a}$, Maira Sá Ferreira ${ }^{a}$, Ana Cristina Gonzalez ${ }^{a}$, Silvia Regina Almeida Reis ${ }^{a}$, Alena Ribeiro Alves Peixoto Medrado ${ }^{a}$

\begin{abstract}
OBJECTIVE: The aim of the present study is to conduct a comparative analysis of oral actinic cheilitis and squamous cell carcinomas by immunohistochemical analysis.

METHODS: This cross-sectional study utilizes a convenience sample obtained from the archives of an oral pathology laboratory from a higher education institution. Tissue sections from patients diagnosed with actinic cheilitis and carcinoma were immunohistochemically analyzed using monoclonal antibodies specific for smooth muscle alpha actin (SMA) and neuron-glial antigen 2 (NG2). Individual cells that stained positive for these proteins were counted in specific fields by means of histomorphometry.

RESULTS: Subsequent statistical analysis revealed a higher number of NG2-positive when compared with SMA-positive cells in both lesion types $(p=0.005)$ and these cells were located adjacent to blood vessels. The differences between normal oral mucosa, severe dysplasia, and carcinoma specimens were statistically significant $(p=0.009 ; p=0.006)$.

CONCLUSION: These data strongly suggest that increased expression of NG2- and SMA-positive cells is associated with formation of blood capillaries, highlighting the importance of angiogenesis in tumor progression.
\end{abstract}

Key words: Carcinoma; Pericytes; Myofibroblasts

\section{Expressão imuno-histoquímica de pericitos e miofibroblastos na matriz extracelular de queilite actínica oral e carcinoma de células escamosas: estudo comparativo}

\section{RESUMO}

OBJETIVO: O objetivo do presente estudo foi realizar uma análise comparativa da queilite actínica e do carcinoma de células escamosas por meio de análise imuno-histoquímica.

MÉTODOS: Este estudo transversal utilizou uma amostra de conveniência obtida dos arquivos de um laboratório de patologia oral de uma instituição de ensino superior. As secções de tecido de pacientes diagnosticados com queiliteactínica e carcinoma foram analisados pela técnica imuno-histoquímica usando anticorpos monoclonais específicos para alfa actina de músculo liso (SMA) e do antígeno neurônio/glial2 (ng2). As células com marcação positiva para estas proteínas foram contadas em campos específicos por meio de histomorfometria.

RESULTADOS: análise estatística subsequente revelou maior número de positivos para ng2 quando comparados com células SMA positivas em ambos os tipos de lesão $(p=0,005)$ seno que estas células foram localizadas adjacentes aos vasos sanguíneos. As diferenças entre mucosa oral normal, displasia grave e espécimes de carcinoma foram estatisticamente significativas $(p=0,009 ; p=0,006)$.

CONCLUSÃO: Os dados sugerem, fortemente, que o aumento da expressão de células positivas para ng2 e SMA está associado à formação de capilares sanguíneos, destacando a importância da angiogênese na progressão tumoral.

Palavras-chave: Carcinoma; Pericitos; Miofibroblastos
${ }^{a}$ Bahiana School of Medicine and Public Health

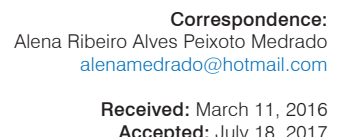

Conflict of Interests: The authors state that there are no financial and personal conflicts of interest that

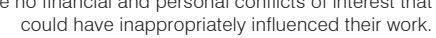
Copyright: @ 2017 Wanderley et al.; licensee EDIPUCRS

This work is licensed under a Creative Commons Attribution 4.0 International License. (c) $\bigoplus_{\mathrm{BY}}$ 


\section{BACKGROUND}

Actinic cheilitis (AC) is a precancerous lesion that can progress into oral squamous cell carcinoma, the most common form of oral cancer, contributing to $95 \%$ of all oral malignancies. Mainly associated with chronic exposure to sunlight or artificial ultraviolet radiation, cheilitis is located on the lower lip, with a higher prevalence in men with leukoderma. The most affected age group corresponds to the $5^{\text {th }}$ decade of life [1].

Although solar radiation is the main risk factor for cheilitis on the lip, other factors, such as smoking, excessive consumption of alcohol, sexually transmitted diseases, ethnicity, genetic and family predisposition, immunosuppressive state, malnutrition and socioeconomic status may also contribute to the development of such lesions [2].

From a clinical point of view, cheilitis is characterized by atrophy of the red edge of the lower lip, accompanied by a flat surface and pale areas with eruptions, which may sometimes show flaking. Histologically, there are several grades of epithelial dysplasia, which is diagnosed when $\geq 2$ of the following characteristics are visible in tissue sections affected by the lesion: the presence or absence of irregular epithelial stratification, basal layer hyperplasias, drop-shaped rete ridges, loss of basal cell polarity, increase of the nucleus/cytoplasm ratio, nuclear polymorphism, increase in the size of nucleoli, nuclear hyperchromatism, reduced intercellular adhesion, suprabasal mitosis and dyskeratosis [3]. The classification of epithelial dysplasia is considered light when 2 of the above characteristics are present; moderate, when 3 to 4 changes are present; and severe, when $\geq 5$ of these histological findings are present, accompanied by lamina propria invasion $[4,5]$.

The malignant progression of this precancerous lesion involves complex interactions between dysplastic cells and the stroma, which undergoes changes during the progression to malignant neoplasia. In squamous cell carcinoma, it is common to see neoplastic cell islands invading the connective tissue, characterized by the presence of pleomorphic cells with clear nuclear hyperchromatism [5]. Corneal keratinization may be observed occasionally.

Changes in the extracellular matrix and the presence of myofibroblasts and pericytes appear to influence the invasion and metastasis processes that characterize oral malignant tumors [6]. Myofibroblasts are specialized mesenchymal cells with properties similar to those of smooth muscle cells and fibroblasts. They are expressed in physiological or pathological conditions as part of the host response to invasion of the tissue. Despite the large body of research that investigated the presence of myofibroblasts in the stroma of squamous cell carcinoma in the oral cavity, there is a dearth of studies describing the involvement of these cells in precancerous lesions. We used immunohistochemical analysis with the anti- smooth muscle alpha-actin (SMA) antibody, known to be a marker for myofibroblasts and pericytes, in order to evaluate the participation of these cells in the context of a dysplastic lesion, particularly in the development of desmoplasia, which is frequently observed in the stroma of malignant tumors [6].

In addition to SMA, the neuron-glial antigen 2 (NG2) monoclonal antibody has been used to identify changes in the tumor stroma, particularly to detect the presence of pericytes associated with new blood capillaries (angiogenesis), and myofibroblasts dispersed in the connective matrix [7]. Pericytes are cells that influence the stability of blood vessels, through extracellular matrix deposition and the activation or production of molecules that promote cell differentiation or endothelial quiescence $[7,8]$. Their biological role in dysplastic lesions, such as AC, remains to be elucidated. We believe that pericytes may contribute to malignant neoplastic progression and promote tumor metastasis by increasing the permeability of the blood vessels. Moreover, the literature on this subject indicates that pericytes may be a precursor of myofibroblasts, and are stem cells that are capable of differentiating into different cell lineages $[9,10]$.

Thus, this study aims to comparatively evaluate the presence of pericytes and myofibroblasts in oral squamous cell carcinoma and epithelial dysplasia (actinic cheilitis) through the immunohistochemical analysis of SMA and NG2 proteins.

\section{METHODS}

\section{Ethics Committee}

The study was submitted to and approved by the Human Research Ethics Committee protocol No. 16962113.1.0000.5544.

\section{Case selection}

Seventeen associated cases of $\mathrm{AC}$ and squamous cell carcinoma of the lip were selected from the oral pathology laboratory of a private University. All these cases originated from surgical specimens of lower lip resection. The anatomopathological diagnosis of tissue sections stained with hematoxylin-eosin (HE) was reviewed and confirmed by two experienced pathologists.

Eight specimens of normal oral mucosa were collected from randomly selected patients (control group) who exhibited retention and mucus extravasation in order to observe the immunohistochemical pattern of antibodies in subepithelial lamina propria of normal lip.

\section{Histopathological analysis}

The histological criteria for diagnosis of epithelial dysplasia, as defined by the World Health Organization (WHO), 1978, were observed in AC lesions [11] and the severity of dysplasia was determined by following the guidelines established by Bánóczy and Csiba, 1976 [4].

The histological evaluation of squamous cell carcinoma of the lip was performed according to the malignancy grading system recommended by the WHO, 2005 [12], which stratifies tumors as poorly, moderately, and welldifferentiated. 
Immunohistochemical procedures

Paraffin-embedded tumor samples were cut into $4 \mu \mathrm{m}$ thick tissue sections, which were mounted on glass slides that had been pre-treated with 3-aminopropyltriethoxysilane (Sigma Aldrich, St. Louis - USA).

The immunohistochemical protocol utilized the streptavidin-biotin (SAB)-peroxidase complex to detect the presence of the target protein; the following monoclonal primary antibodies were used: anti-SMA (1:200) (Dakocytomation, Denmark) and anti-chondroitin sulfate proteoglycan/neuron-glial antigen 2 (NG2) (1:200) (Millipore, California, USA). Histological sections were deparaffinized in sequential baths with xylene, acetone, ethanol (absolute, $95 \%, 70 \%, 50 \%, 30 \%$ ), and distilled water at room temperature. Next, antigen retrieval was performed using citrate buffer ( $\mathrm{pH}$ 6.0), followed by blocking for nonspecific binding ( $10 \%$ skim milk), then incubated overnight at $4{ }^{\circ} \mathrm{C}$ with primary antibody. The secondary antibodies used followed the guidelines of the SAB-peroxidase kit (DAKO Corporation, USA) and developing was performed using DAB (Dako Corporation, USA) with 30\% hydrogen peroxide. The slides were counterstained with Harris' hematoxylin and mounted under a cover slip with Canada balsam for morphological and quantitative analysis. Previously resected human liver sections were used as positive- or negative- controls, based on the inclusion or omission of the primary antibodies, respectively.

\section{Histomorphometry}

The quantitative study of cells that showed positive staining for smooth muscle alpha-actin and NG2 was performed using the Motic Images Advanced 3.0 $0^{\circledR}$ software (Motic China Group CO. LTD). Before using the program, the calibration for each variable was checked with a standard image that was based on a calibration slide provided by the manufacturer. Sections of normal, dysplastic, and cancerous tissues were carefully examined in 4 random fields of $0.1 \mathrm{~mm}^{2}$. Next, each area was photographed at $40 \mathrm{X}$ magnification and saved in JPEG format.

Cells that stained positive for SMA and NG2 and were present exclusively in the connective tissue stroma in the normal, dysplastic, and neoplastic sections of the oral mucosa were quantified. Only perivascular cells and those individually dispersed in the extracellular matrix that showed a positive staining pattern were included in the morphometric analysis. The results were tabulated in an Excel spreadsheet. All analyses were conducted by the same blinded examiner to avoid bias.

\section{Statistical analysis}

Because of the non-normal distribution of data, the Kruskal-Wallis test was used followed by the Mann-Whitney test, and Fisher exact test with Bonferroni correction. The medians and their respective interquartile ranges were calculated. The significance level for the study was $5 \%$ $(\mathrm{p}<0.05)$.

\section{RESULTS}

Lesions were classified by histological level according to the anatomopathological study of the tissue sections stained with hematoxylin-eosin from dysplasia (cheilitis) and carcinoma. Of the 17 dysplasia specimens, 3 (17.6\%) were classified as light, 9 (52.9\%) as moderate, and 5 (29.4\%) as severe. Based on the histological dysplastic changes, irregular epithelial stratification was found to be the most common atypia, followed by nuclear hyperchromatism, drop-shaped rete ridges and basal layer hyperplasia. With regard to the carcinoma classification, $14(82.3 \%)$ were welldifferentiated, and $3(17.6 \%)$ were moderately differentiated. None of the specimens showed non-differentiated squamous cell carcinoma.

The immunohistochemical staining pattern appeared more intense in the tissue sections treated with anti-SMA, than those treated with NG2 antibody, where staining was more diffuse.

In tissue sections from normal mucosa (control), a similar staining pattern was observed for cells that stained positive for SMA and NG2 ( $p>0.05)$ (Table 1). In general, the tissue sections derived from dysplastic lesions showed a higher number of NG2-positive cells $(\mathrm{p}<0.05)$ irrespective of their degree of categorization; these cells were located adjacent to the endothelial lining of small vessels. This finding was statistically significant when compared to the number of SMA-positive cells $(p=0.001)$ (Figure 1) (Table 1). The oral squamous cell carcinoma showed a higher number of NG2-positive cells when compared to SMA-positive cells, with a statistically significant difference $(p=0.005)$ (Table 1). Numerous blood capillaries and small arterioles were observed adjacent to the islands and nests of neoplastic cells, exhibiting central corneal keratinization (Figure 2).

In oral squamous cell carcinoma there were more NG2-positive than SMA-positive cells, with a statistically significant difference $(p=0.005)$ (Table 1). Numerous blood capillaries and small arterioles were observed adjacent to the islands and nests of neoplastic cells, exhibiting central corneal keratinization (Figure 2).

Table 2 compares the number of SMA-positive and NG2-positive cells among the different lesion types under study. We observed that, although there were progressively more SMA-positive cells in the lesions than the control, this difference was not statistically significant $(\mathrm{p}>0.05)$. The greater number of NG2-positive cells were present in the severe dysplasia specimens $(\mathrm{p}=0.009)$. This lesion exhibited cytoplasmic expression of NG2, and cells were primarily located at the periphery of small blood vessels (Figure 3). There were no statistically significant differences between the different degrees of dysplasia. The carcinoma specimens exhibited a significant difference in the number of NG2-positive cells present in the normal oral mucosa and in the moderately differentiated carcinoma $(\mathrm{p}=0.006)$. 
Table 1. Quantitative analysis of SMA and NG2-positive cells in normal oral mucosa (control), oral dysplasia, and oral squamous carcinoma

\begin{tabular}{|c|c|c|c|c|}
\hline \multirow{2}{*}{$\begin{array}{l}\text { Study } \\
\text { Group }\end{array}$} & \multicolumn{2}{|c|}{ ACTA2 $+{ }^{a}$ Cells } & \multicolumn{2}{|c|}{ NG2 $+{ }^{b}$ Cells } \\
\hline & Median & $\begin{array}{c}\text { Quartiles } \\
\text { (Q1-Q3) }\end{array}$ & Median & $\begin{array}{c}\text { Quartiles } \\
\text { (Q1-Q3) }\end{array}$ \\
\hline Control & 47.1 & $23.4-81.7$ & 46.4 & $25.2-70.1$ \\
\hline Dysplasia ${ }^{1}$ & 53 & $34.4-92.0$ & 155.7 & $116.3-215.3$ \\
\hline Carcinoma $^{2}$ & 92.3 & $68.5-116.9$ & 160.4 & $145.0-241.4$ \\
\hline
\end{tabular}

Kruskal Wallis test, followed by Mann-Whitney test with Bonferroni correction $(\mathrm{a}, \mathrm{b}) \mathrm{p}<0.05$

Kruskal Wallis test, followed by Mann-Whitney test with Bonferroni correction $(a, b) p<0.05$
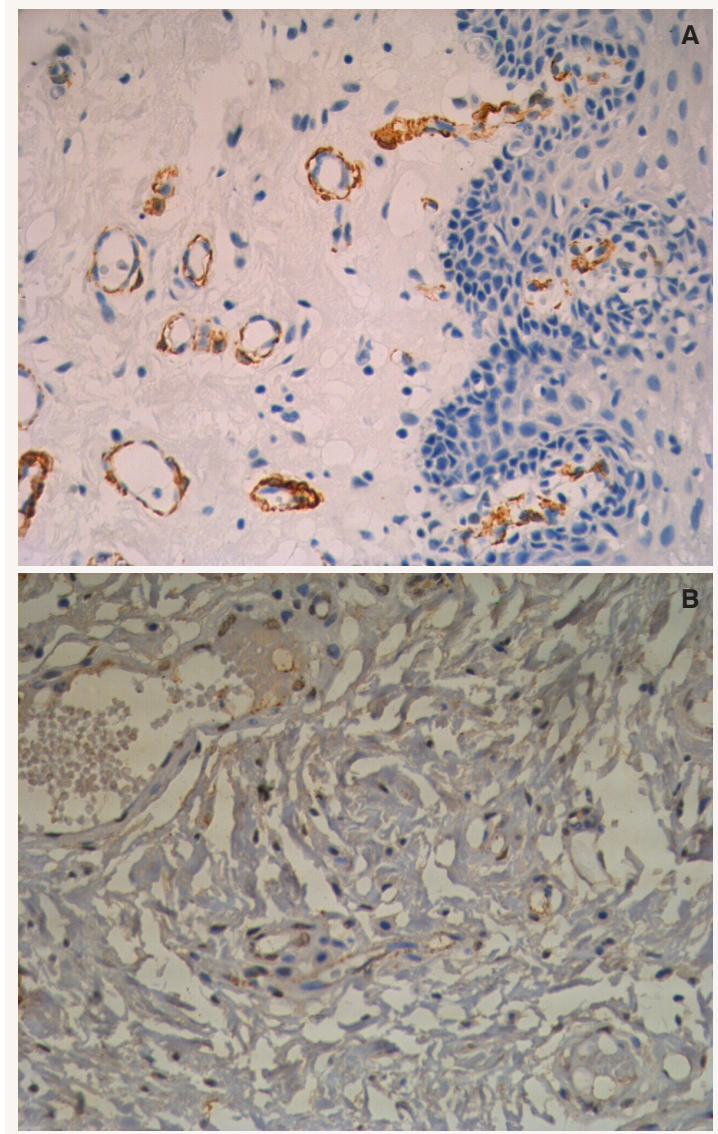

Figure 1. Immunohistochemical expression of SMA (A) and NG2 (B) in cells located adjacent to the endothelial lining present in sections of Dysplasia

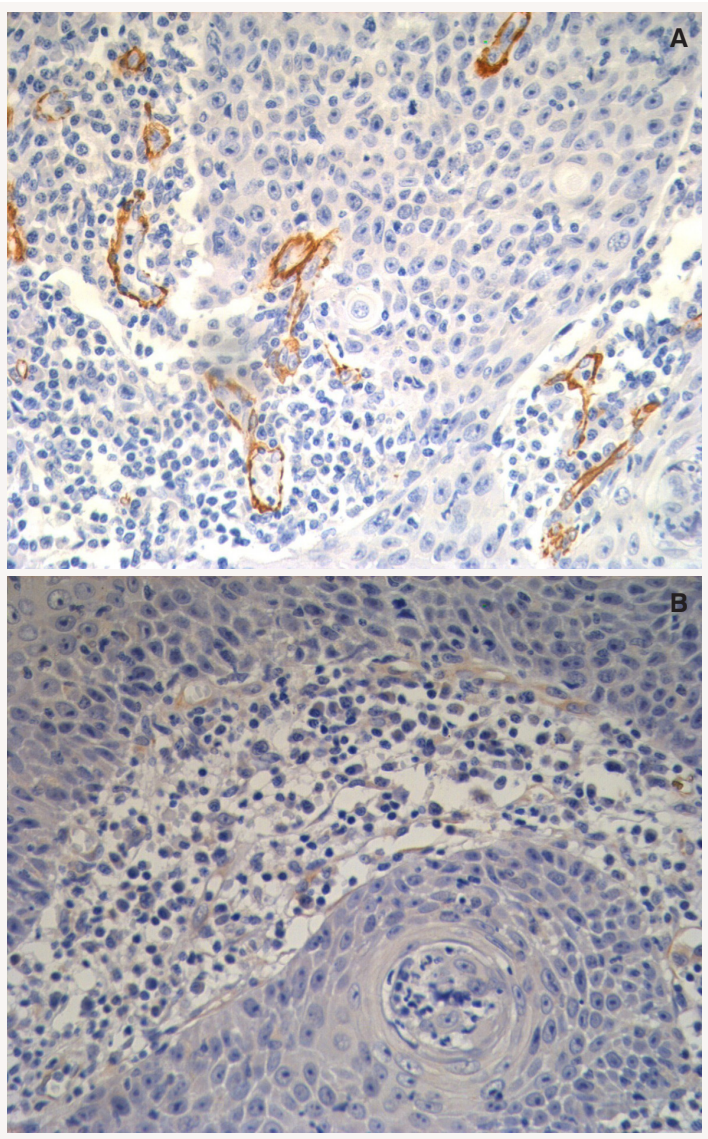

Figure 2. Immunohistochemical expression of SMA (A) and NG2 (B) in cells located adjacent to the endothelial lining present in carcinoma sections

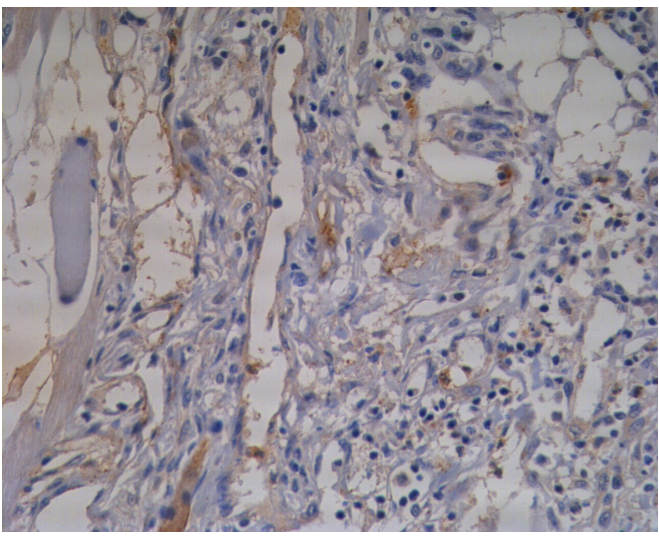

Table 2. Immunohistochemical expression of SMA and NG2 in cells from normal oral mucosa (control), different degrees of dysplasia, and oral squamous carcinoma specimens

\begin{tabular}{lcc}
\hline \multicolumn{1}{c}{ Study Group } & Cells ACTA2+ & Cells NG2+ $^{1}$ \\
& Median (Q1-Q3) & Median (Q1-Q3) \\
Control $^{\mathrm{a}}$ & $47.1(23.4-81.5)$ & $46.4(25.2-70.1)$ \\
Mild dysplasia $^{\mathrm{b}}$ & $53.0(33.7-53.0)$ & $122.7(107.5-0)$ \\
Moderate dysplasia $^{\mathrm{c}}$ & $62.7(33.3-92.0)$ & $146.0(94.0-207.6)$ \\
Severe dysplasia $^{\mathrm{d}}$ & $53.0(38.3-132.1)$ & $217.7(157.8-240.2)$ \\
Well differentiated carcinoma $^{\mathrm{e}}$ & $85.5(63.9-123.2)$ & $158.4(141.3-278.6)$ \\
Moderately differentiated carcinoma $^{\dagger}$ & $103.2(78.5-0)$ & $166.9(155.7-0)$ \\
\hline
\end{tabular}

Kruskal-Wallis test, followed by Mann-Whitney test with Bonferroni correction $(a, d) p=0.009$; $(a, f) p=0.006$
Figure 3. NG2 + cells located in the basal membrane of blood capillaries in severe oral dysplasia 


\section{DISCUSSION}

According to one study, AC is very common in Brazil, owing to the population's high-exposure to solar radiation, especially those employed in outdoor activities for long periods of time, such as farmers, fishermen and construction workers [13].

$\mathrm{AC}$ is a potentially malignant lesion that is associated with chronic sun exposure. The cumulative effect of solar radiation on human tissues explains why $\mathrm{AC}$ is more prevalent in older individuals [14].

It is well-known that melanin provides added protection to the skin from sunlight. Thus, $\mathrm{AC}$ is rare in individuals with high levels of melanin pigmentation [15]. Moreover, it is found more frequently in men, as women have additional protection through the use of lipstick with sun protection factor [16].

As the lower lip occupies a more prominent anatomical position on the face than the upper lip, it receives higher exposure to solar radiation. Consequently, AC is more prevalent in the lower lip [17].

Therefore, this study aimed to compare the presence of SMA-positive and NG2-positive cells in precancerous lesions and squamous cell carcinoma, in order to better understand the contribution myofibroblasts and pericytes in neoplastic progression. Although the ultimate identification of these cells can only be effectively confirmed through transmission electron microscopy, some authors have used immunohistochemistry for the analysis of these cellular elements $[18,19]$.

A total of 17 cases of squamous cell carcinoma of the lip associated with AC were analyzed in this study. In 1981, other authors described $\mathrm{AC}$ as a malignant lesion capable of developing a malignant phenotype [8]. In other study one author also correlated cases of epithelial dysplasia and squamous cell carcinoma in a cohort of 41 patients [3]. Although our study sample was smaller, it enabled the morphometric analysis and statistically significant data were obtained.

It is well-known that there is a high degree of variation in epithelial dysplasia observed in the oral mucosa of patients with $\mathrm{AC}$, and this can be determined by the number and type of histological changes present in the lesion's microenvironment. Others authors studied 35 cases of $\mathrm{AC}$ and observed that 17, 13 and 5 patients showed light, moderate, and severe dysplasia, respectively [20]. In the present study, we observed that, when present, epithelial dysplasia ranged from light to severe; only 2 cases showed no histological changes, which are characteristic of atypia. Despite the existence of different grading systems for epithelial dysplasia, studies should consider the examiner's subjectivity as a relevant variable. As a result, the classification of Banoczy and Csiba and the analysis of the histological sections by 2 previously calibrated pathologists were adopted [4].

Of the histological dysplasia changes observed in this study, irregular epithelial stratification was the most common atypia, followed by nuclear hyperchromatism, drop-shaped rete ridges, and basal layer hyperplasia. However, other authors reported loss of basal cell polarity and nuclear hyperchromatism as the most frequently described atypia in dysplastic lesions in their studies, followed by nuclear polymorphism, and drop-shaped rete ridges [21]. Most cases of lip squamous cell carcinoma were well differentiated. This result might be explained by the fact that lesions that affect the lip are generally well differentiated [22].

Many authors have described myofibroblast involvement in the tumor's progression [23,24]. It has long been believed that these cells originated from pre-existing fibroblasts [25]. In an immunohistochemical and ultrastructural study, other authors demonstrated that such cells can originate from the differentiation of pericytes, as both myofibroblasts and pericytes share the same immunohistochemical staining pattern for SMA and NG2 antibodies [7]. The impact of myofibroblasts in tumor progression can be attributed to the collagen biosynthesis by these cells, a fact that would greatly contribute to the establishment of desmoplasia in the tumor's extracellular matrix. Some studies suggest that, in addition to their contractile property, myofibroblasts may interfere with the degree of neoplastic tissue elasticity, and clinically show tumor retraction $[26,27]$.

Although it was not the primary objective of this study, angiogenesis is extremely important in cancer progression, because the capillaries that usually form during neoplasm development are unstable and their inherent permeability promotes tumor metastasis [28]. In addition to the active participation of endothelial cells in this context, pericytes are derived from the mesenchymal lineage of smooth muscle cells, which exist as individual cells that share the basal membrane of blood vessels with endothelial cells [29]. The pericytes make focal contacts with the endothelium via specialized junctions and long cytoplasmic extensions that extend and surround the endothelial tube. Furthermore, these cells influence the stability of the vessel through matrix deposition and/or release and activation of signals that promote differentiation and quiescence of endothelial cells $[6,30]$. In addition to the aforementioned biological actions, new studies have suggested an additional role for pericytes. These cells may have pluripotent cell characteristics, thereby constituting an important "cell reservoir". Although the plasticity of pericytes has not yet been extensively studied, there are reports on their potential to differentiate into osteoblasts, chondrocytes, fibroblasts, leiomyocytes and adipocytes $[9,31]$. In this study, immunohistochemical analysis showed that the vast majority of SMA-positive and NG2-positive cells were located in the endothelial lining wall, confirming that they were pericytes. These data suggest that pericytes may contribute to the tumor's progression, by making the newly formed blood vessels more permeable and promoting the hematogenous dissemination of cancer cells.

Other authors immunohistochemically analyzed the presence of myofibroblasts in the extracellular matrix of normal oral mucosa and failed to detect any myofibroblasts 
in the 10 samples studied [32]. In this study, a similar staining pattern was observed for SMA and NG2-positive cells $(p>0.05)$ in 8 tissue sections from normal oral mucosa (control); this represents the physiological vascular distribution, which helps to identify the pericytes. In these samples, NG2 and SMA-positive cells were exclusively observed in the region adjacent to the wall of blood capillaries and arterioles.

When normal oral mucosa progresses towards malignancy, lesions such as leukoplakia, erythroplakia and actinic cheilitis begin to display varying degrees of dysplasia. According to one study, myofibroblasts are usually not observed on the lamina propria during dysplastic changes associated with leukoplakia; significant numbers of these cell types are thought to be closely associated with the metastasis of the underlying connective tissue [23]. In this study, although dysplastic lesions were found to have been associated with AC, SMA-positive cells were present on the lamina propria underlying the epithelial tissue of the vessel wall $(\mathrm{p}>0.05)$. No isolated SMA or NG2-positive cells were observed in the connective tissue located farther from the epithelium that might be considered as myofibroblasts. This finding suggests that neovascularization is the most significant phenomenon for neoplastic progression, as these SMA and NG2-positive cells represent pericytes. Moreover, these cells were located in the vessel wall and shared the basal lamina of the endothelial cells. The location of pericytes in dysplastic lesions may be related to the pathological neovascularization [33].

The presence of myofibroblasts appears to be less common in the tumor stroma of carcinomas, whereas cells with pericyte characteristics are more frequent in the stroma associated with dysplasia and carcinomas. Other authors investigated the expression of myofibroblasts in the neoplastic invasion of squamous cell carcinoma [27]; they observed that SMA-positive cells located adjacent to vessels and budding capillaries, similar to pericytes. Both cases presented by the authors were of highlyaggressive carcinomas that were intensely vascularized. The morphometric analysis of oral squamous cell carcinoma lesions revealed that SMA-positive cells were only visible in the region adjacent to arterioles and budding capillaries, indicating that these cells were pericytes. However, the differences between the control group and the different dysplasia samples were not statistically significant $(p>0.05)$.

\section{CONCLUSION}

The results of this study suggest that the pericyte is the key cellular element responsible for neoplastic progression. Although this study was not focused on angiogenesis, the increased expression of NG2 and SMA-positive cells associated with blood capillaries highlights the relevance of this biological process in the context of tumor progression. We propose that these pericytes may act through a signaling pathway to stimulate neoplastic cells and induce marked changes in the stroma, so as to biomodulate the metastasis process. Notably, these cells differentiate into myofibroblasts and produce larger amounts of collagen, which characterizes desmoplasia.

\section{REFERENCES}

1. Vieira RA, Minicucci EM, Marques ME, Marques SA. Actinic cheilitis and squamous cell carcinoma of the lip: clinical, histopathological and immunogenetic aspects. An Bras Dermatol 2012;87(1):105-14.https://doi. org/10.1590/S0365-05962012000100013

2. Ribeiro CF, Souza FH, Jordão JM, Haendchen LC, Mesquita L, Schmitt JV, et al. Photodynamic therapy in actinic cheilitis: clinical and anatomopathological evaluation of 19 patients. An Bras Dermatol 2012;87(3):418-23. https://doi.org/10.1590/S0365-05962012000300011

3. Gomes AP, Johann JE, Lovato GG, Ferreira AM. Comparative analysis of the mast cell density in normal oral mucosa, actinic cheilitis and lip squamous cell carcinoma. Braz Dent J 2008;19(3):186-9. https://doi. org/10.1590/S0103-64402008000300002

4. Banoczy J, Csiba A. Occurrence of epithelial dysplasia in oral leukoplakia. Analysis and follow-up study of 12 cases.Oral Surg 1976;42(6):766-74. https://doi.org/10.1016/0030-4220(76)90099-2

5. Costa NL, Leite AFO, Junior APC, Alencar RCG, Bittar GOJ, Silva TA Batista AC. Density and migration of mast cells in lip squamous cell carcinoma and actinic cheilitis. Histol Histopathol 2009;24(4):457-65.

6. Xian X, Håkansson J, Ståhlberg A, Lindblom P, Betsholtz C, Gerhardt $\mathrm{H}$, Semb H. Pericytes limit tumor cell metastasis. J Clin Invest 2006;116(3):642-51. https://doi.org/10.1172/JCl25705

7. Medrado A, Costa T, Prado T, Reis S, Andrade Z.Phenotype characterization of pericytes during tissue repair following low-level laser therapy. Photodermatol, Photoimmunol Photomed2010;26(4):192-7.https://doi. org/10.1111/j.1600-0781.2010.00521.x

8. Cataldo E, Doku HC. Solar cheilitis. J Dermatol Surg Oncol. 1981; 7(12):989-95. https://doi.org/10.1111/j.1524-4725.1981.tb00203.x

9. Von Tell D, Armulik A, Betsholtz C.Pericytes and vascular stability. Exp Cell Res 2006;312(5):623-9. https://doi.org/10.1016/j.yexcr.2005.10.019

10. Hinz B, Phan SH, Thannickal VJ, Galli A, Bochaton-Piallat ML, Gabbiani G. The myofibroblast. Am J Pathol 2007;170(6):1807-16. https://doi. org/10.2353/ajpath.2007.070112

11. Kramer IR, Lucas RB, Pindborg JJ, Sobin LH. Definition of Leukoplakia and related lesions: an aid to studies on oral precancer. Oral Surg Oral Med Oral Pathol 1978;46(4):518-39. https://doi.org/10.1016/00304220(78)90383-3

12. Barnes L, Eveson, JW, Reichart P, Sidransky D. World Health Organization classification of tumours. Pathology and Genetics of Head and Neck Tumours. IARC Press: Lyon; 2005

13. Martins-Filho PR, Da Silva LC, Piva MR. The prevalence of actinic cheilitis in farmers in a semi-arid northeastern region of Brazil.Int J Dermato 2011;50(9):1109-14. https://doi.org/10.1111/j.1365-4632.2010.04802.x

14. Lucena EES, Costa DCB, Silveira EJD3, Lima KC. Prevalence and factors associated to actinic cheilitis in beach workers. Oral Dis 2012;18(6):575-9. https://doi.org/10.1111/j.1601-0825.2012.01910.x

15. Sarmento DJS, Miguel MCC, Queiroz LMG, GP Godoy, da Silveira EJD. Actinic cheilitis: clinicopathologic profile and association with degree of dysplasia. Int J Dermatol 2014;53(4):466-72. https://doi.org/10.1111/ ijd.12332

16. Pires FR, Bueno RH, Alves FA, Almeida OP. Queilite actínica: aspectos clínicos e preventivos. Rev Assoc Paul Cir Dent 2001;55(3):200-3.

17. Piñera-Marques K, Lorenço SV, Silva LFF, Sotto MN, Carneiro PC. Actinic lesions in fishermen's lower lip: clinical, cytopathological and histopathologic analysis. Clinics 2010;65(4):363-7. https://doi. org/10.1590/S1807-59322010000400003

18. Lúcio PS, Cavalcanti AL, Alves PM, Godoy GP, Nonaka CF. Myofibroblasts and their relationship with oral squamous cell carcinoma. Braz Otorhinolaryngol 2013;79(1):112-8. https://doi.org/10.5935/18088694.20130019

19. Mărgăritescu $C$, Simionescu $C$, Pirici D, Mogoantă L, Ciurea R, Stepan A. Immunohistochemical characterization of tumoral vessels in oral squamous cell carcinoma. RJME 2008;49(4):447-58

20. Araújo CP, Xavier FCA, Gurgel CAS, Ramos EAG, Freitas VS, SchlaepferSales CB, et al. Elastin accumulation in actinic cheilitis with different degrees of epithelial dysplasia. Int J Morphol 2012;30(2):627-33. https:// doi.org/10.4067/S0717-95022012000200044

21. De Freitas MCA, Ramalho LMP Xavier FCA, Moreira ALG, Reis SRA. p53 and MDM2 protein expression in actinic cheilitis. J Appl Oral Sci 2008;16(6):414-9. https://doi.org/10.1590/S1678-77572008000600011 
22. Beltrami CA, Desinan L, Rubini C. Prognostic factors in squamous cell carcinoma of the oral cavity. A retrospective study of 80 cases. Pathol Res Pract 1992;188(4-5):510-6. https://doi.org/10.1016/S0344-0338(11) 80047-6

23. Kellermann MG, Sobral LM, da Silva SD, Zecchin KG, Graner E, Lopes MA et al. Myofibroblasts in the stroma of oral squamous cell carcinoma are associated with poor prognosis. Histopathol 2007;51(6):849-53. https:// doi.org/10.1111/j.1365-2559.2007.02873x

24. Schürch W, Seemayer TA, Lagacé R. Stromal myofibroblasts in primary invasive and metastatic carcinomas. A combined immunological, ligh and electron microscopic study. Virchows Arch A Pathol Anat Histo 1981;391(2):125-39. https://doi.org/10.1007/BF00437591

25. Daly AJ, Mcllreavey L, Irwin CR. Regulation of HGF and SDF-1 expression by oral fibroblasts - implications for invasion of oral cancer. Oral Oncol 2008;44(7):646-51. https://doi.org/10.1016/i.oraloncology.2007.08.012

26. Nielsen JD, Moeslund M, Wandall HH, Dabelsteen S. Influences of tumo stroma on the malignant phenotype. J Oral Pathol Med 2008:37(7):412-6. https://doi.org/10.1111/j.1600-0714.2008.00655.x

27. Martins GB, Ribeiro MB, Reis SRA. Análise de miofibroblastos no estroma de carcinoma epidermoide da boca. Rev pós-grad 2011;18(4):244-52.

28. Folkman $\mathrm{J}$. Role of angiogenesis in tumor growth and metastasis Semin Oncol 2002;29(6 Suppl 16):15-8. https://doi.org/10.1016/S00937754(02)70065-1
29. Crocker DJ, Murad TM, Geer JC. Role of the pericyte in wound healing An ultrastructural study. Exp Mol Pathol 1970;13(1):51-65. https://doi. org/10.1016/0014-4800(70)90084-5

30. Takakura N. Role of hematopoietic lineage cells as accessory components in blood vessel formation. Cancer Sci 2006:97(7):568-74. https://doi. org/10.1111/j.1349-7006.2006.00223.x

31. Farrington-Rock C, Crofts NJ, Doherty MJ, Ashton BA, Griffin-Jones C Canfield AE. Chondrogenic and adipogenic potential of microvascular pericytes. Circulation 2004;110(15):2226-32. https://doi.org/10.1161/01 CIR.0000144457.55518.E5

32. Sridhara SU, Choudaha N, Kasetty S, Joshi PS, Kallianpur S, Tijare M. Stromal myofibroblasts in nonmetastatic and metastatic oral squamous cell carcinoma: An immunohistochemical study. J Oral Maxillofac Patho 2013;17(2):190-4. https://doi.org/10.4103/0973-029X.119758

33. Ozerdem U, Stallcup WB. Early contribution of pericytes to angiogenic sprouting and tube formation.Angiogenesis 2003;6(3):241-9. https://doi. org/10.1023/B:AGEN.0000021401.58039.a9 